\title{
Teaching Portuguese as a foreign language, in University Malaya
}

\author{
Maria Cristiana CASIMIRO
}

\begin{abstract}
In this text, I refer to my experience teaching already for 8 semesters in University Malaya, Kuala Lumpur, putting together the experience I am having here, the characterization of my students, of the place, of the society, and also using my previous experience in other different countries, in order to improve myself every day, to became a better Portuguese lecturer and, therefore, being able to motivate my students. This will increase their interest being in my classroom and also lead to much better results.

I cannot dissociate my self from my origins, my countries (Portugal and Mozambique), my influences, the way I was raised by my parents, and the experiences I have experienced all my life, which I tried to use, always, to learn something new, to became a better person and a better teacher. Because teaching, is my passion, mostly teaching Portuguese as a foreign language.

In my classes, and teaching Portuguese as an optional language, I emphasize mostly the communication, trying a communicative approach. In order to do that, I use culture marks, new greetings forms (compared to the ones we see in Asia), forms of addressing people, promoting dialogue in all classes. So, I have to give them, in a very simple way, the basics of my language, the grammar, the new phonetic (some sounds totally new).

Like I tell them, learning a new language, is almost like playing a puzzle (where we have to look at the shapes of all little pieces). Here, he have to look at the words, the meanings we have already learned (semantic), and combine it with the very simples rules we know, in order to form a sentence, in order to communicate.

Because Communication, this is important for me, because speaking and being able to say what we have to say (in a correct way), helps us to be understood, and this can help solving a lot of troubles, in our schools, societies, countries, in the world.

We have a proverb “A falar é que a gente se entende!”. That is, exactly, my point!
\end{abstract}


Index terms: Learning; Portuguese Soul, Language and Culture; Malaysia.

In November 2007, it will be four years, since I am teaching my mother tongue, in Kuala Lumpur, as a Portuguese lecturer of Portuguese language.

Since the beginning, I was aware of the responsibility doing something like this, because I really think that, if you are teaching your language in a foreign country, you are not simply doing it, but you are also "showing" another culture, another way of thinking and of life. For me, teaching Portuguese, here (considering that it is only optional and students may learn it only for a semester), is like opening another door, to a different world and culture, just open, may be one day, later, some students will decide to enter in, and really see what is there, behind that door. One thing I like most, here, is that in only one class, I am able to find people belonging to four different religions and cultures, this gives me the possibility to try to understand their world, their culture and way of life, and this is always good, if you are aware of your own world, culture, religion, way of life. So, I feel myself richer, since I am here, because I have to communicate with people living in other cultures, I have to try to reach their minds, ways of understanding me, when I am trying to transmit a little bit of my language, my culture and my way of life. And this, both ways (from them to me and from me to them), is not complete only in the classroom, but in every place where we meet, where we communicate.

And Communication is like the most important thing to me. Our Portuguese Poet Fernando Pessoa once wrote “A minha Pátria é a língua Portuguesa” - My Homeland is the Portuguese Language- (In: SIMÕES, 1991). This is exactly how I feel, but is not as simple as that; I was born in Mozambique, to Portuguese parents (my father from Coimbra and my mother from Lisboa. My father was a doctor, and they went to Mozambique 
in 1952 0r 1953, mainly because of political reasons connected to the dictatorship Salazar's, in Portugal, that time. I lived in Mozambique until I was 22 years old, obtained my first University Degree in Universidade Eduardo Mondlane, and then I left to East Germany, where I was 4 years, teaching Portuguese in the "Schule der Freundschaft, Stassfurt". After that I went to Portugal, where I worked and continued my studies. In year 2000, I was the first Portuguese Teacher arriving in Oecusse (the Enclave), in Timor-Leste, since 1975, the Invasion. I was working in Timor Leste for 3 years, after which I came to Kuala Lumpur. I think that, considering all these places where I have worked (and enjoyed a lot doing so), teaching my mother tongue, one is able to understand that I consider my self a little bit as citizen of the world, although I feel very Portuguese within myself, speaking about soul, poetry, dreaming, I am really able to find what I am in the Fado songs, in the Portuguese Lyric, so I guess my soul is a Portuguese one. But I was born and raised in Africa, and this fact added something, for ever, to what I am, I became, and I intend to be. My parents always tried to show us more about the world outside, music, culture, films, religions, etc, and made sure we would be able to respect all these differences (in order to get respected ourselves). So I guess it was not very difficult to have lived and worked in such different countries, and trying to know and understand the people living there. As a result of me trying to get in touch, more profoundly, with the people, there is a book, edited and published this year in Portugal, "Lendas de Timor, Baucau, e Outras histórias" (In: CASIMIRO, 2007). This book is the result of a Home Work I have asked them to do, writing about traditional stories, in their villages, after we had studied a couple of Legends from Timor Leste I managed to find. Here, in Malaysia, I try to do something similar, getting to know more about the culture (should say cultures, at least 4 - Malay, Chinese, Hindi and Eurasian), religions, stories, etc. My students have been writing about it 
already for 5 semesters, and they seem to be much more motivated when I ask them to write about themselves.

So much, just to explain who I am and what, I think, influences me and my work.

Behind the book I use to teach Portuguese (which I am able to give one to each student, making it easier to teach), we may see other ways of acting and living, and I really try to explore these aspects, trying to raise their interest and motivation, being and participating in all process of teaching-learning (and I have to consider that I have taught something only if they have learned it).

When I was a student myself, there were some books helping me to understand things and trying better ways to explain it in the future. I have always liked studying grammar, but I also thought that the importance of grammar is only to help understanding some sentence, some word, in context, and only that way, considering that, in a basic level, the most important thing to do is getting the information and being able to deliver it, using the grammar to help this process, nothing more. And it is really like playing a game, a puzzle, you just have to know the rules and understand the pieces, the words, playing a game where you will go to different levels, making the play more interesting and reaching a goal: be able to present your self and others, in Portuguese, be able to give some information about you and others, places and things, describing people, places and objects, in a very basic level. This is what I may expect from the majority of my students, studying Portuguese only for a semester, about 50 hours. I also tell them, I expect all of them to participate in all process, being there totally, in the classroom, to reason and to do all the exercises (oral or written) I ask them to, as a journey by which we accomplish our goal.

To help me doing this, I have counted with two main books, which ideas I am using also to write this article: 
“Bases da Análise Lingüística”, from Francoise Dubois Charlier, and “Nova Gramática do Português Contemporâneo” (2001) from Celso Cunha and Lindley Cintra.

Language should be seen as an assemblage of complexes processes, as a result of a way of thinking and perceiving reality, this determined by our social life. Being a grammar system, belonging to a group of persons, expressing their conscience of the collectivity, the language reflects how they conceive the world around and try to act, in this situation.

Sociolinguistic, a relatively new branch of linguistic, studies the language as a social phenomenon, and told us how important the relations between language and society are, and that we need to precise it better, in order to understand better the forms they may assume. It is truth that language has an influence in our society and also that society influences our language, considering language as an instrument of social communication, malleable and various, in all its aspects. People use it to express themselves, living in social, cultural and geographically different societies.

So, if a language may consider various systems, different ways of realization being dynamic, we may also admit various norms, representing models, all inside the possibilities we have by realizing this linguistic system. This means that the norm may differ, inside the same linguistic community, implying some grammar liberalism, considering the relatively new situation of the Portuguese language in the world, with the Independence of the former Portuguese Colonies (Angola, Moçambique, Guiné-Bissau, Cabo Verde and S. Tomé e Príncipe), in the last 30 years, and also the fact that Brasil speaks Portuguese with a different accent and some differences in the norm. People in the new African Portuguese speaking countries, and also in Timor Leste, they will speak my language in a different way, but it will still be Portuguese, only richer, suiting all the possible dynamism in a language used to communicate among people from totally different origins, cultures, countries and mother languages. And we 
may considering already correct, the use of so many new words, people use in African Portuguese speaking countries, trying to express their thoughts and visions in another language, the official one in their countries, but not their mother language. Normally, this process reports to old words in Portuguese with rules from mother language, or just using the old terms to build new words following the rules, but in a way we were not use to do. Sometimes, they just take some words from their mother languages, and apply it, following the rules of the Portuguese grammar. This is always a very interesting and rich process, in my opinion, because some of these new words, are really like a metaphor, they imply the meaning of many different things, all coming together, to create a deeper meaning of a concept, an idea.

Communication is the transmission of a message from someone to someone: a sender or a transmitter, a channel, a receptor and the message, formulated following a predetermined code. The message may only be understood if they use the same code. This only code permits the transmission of an endless number of messages, following rules. But these rules, this norm, like I already wrote above, can be malleable, considering the situation of my language in 8 speaking countries.

Linguistic tries to describe and to explain the language. This study of the language has to be conducted in different camps of this language, in order do precise descriptions, helping us to understand better and better. Se, we consider: Phonetic, Semantic and Syntax.

Phonetic studies the sounds of a language. There are common sounds in many languages, but there are also some ones really different and, as a foreign learner, you may have difficulties pronouncing it, because these sounds don't exist in your mother language, so physically, you are not used to do it. In Portuguese, we feel it, when students try to pronounce sounds like diphthongs ao ei oi ou and the nasal ão. I ask them to feel the string in their noses, moving a little bit, when they pronounce that nasal sound. If they feel it, so it was correct. Another issue is the letter H. In Portuguese we 
don't read this letter, if placed in the beginning, but in the middle $\mathrm{H}$ hast to be together with other letter, forming one digraph $l h n h c h$, having a different and palatal sound.

Semantic studies the meanings, all the possible senses of the word, referring to a context, and here we have to consider the denotative sense and the connotative or figurative sense. Not in level 1, but maybe after 100 hours, we should show our students how to use a dictionary, in order to use all the information we may get in. Last semester, I asked my students to write about Malaysia, language and culture (applied to each one), and most of them began writing: "Malaysia is a peaceful country where coexist different races, languages, cultures and customs” (...) It is true and actually, a very good way to begin, but, when they were looking for the translation word in Portuguese, they just choose the first one, so they wrote : "A Malásia é um país onde coexistem corridas e alfândegas diferentes.” Actually, they wrote "Malaysia is a country where coexist races (meaning car or horse races, races like to run), and customs (like the place where we go to clear our goods, arriving or leaving some place). I had many examples like this, sometimes it was hard to understand what they meant, but I felt happy with the result, because they were trying to write something, to explain to me, a foreigner in their country, how things are, in Malaysia, how they see, prepare and live the most important days, all of them. Like I tell them in class, if they don't try to produce some text (oral or written) doing mistakes, they don't give me the opportunity to correct it, and they wont learn. But they produced a wonderful work, not only in Portuguese, also writing about the Malaysian society, so well, that (out of 117 Works) 55 of them won prizes, in an organized literary context.

The Syntax studies all the possible combinations with words, in sentences. Therefore, it is important to know the exact function of some group of words, the role they are playing, in this sentence, like having a complete meaning. I choose to explain, in the first or second week, these 
functions, presenting immediately the language as a system, where each word as a role to play, and where we have rules to connect words coming from each one of those groups. And I really believe that, if you understand the way it works in a language system, no matter what language you are studying, you will be able to apply it to a different language, because the roles and the rules are basically the same (speaking in a very basic level). I came to the conclusion, after 3 semesters teaching in Malaysia, that the students who were able to learn English in a good way, it was easier for them to learn Portuguese, although the English grammar is easier then the Portuguese. In Malay language, there are no gender and no number, and you make plural in a different way, so I can imagine that it will be difficult to my students to have to think always in terms of Masculino or Feminino, Singular or Plural. And also in the Verb Tenses (we have a lot of them, but actually we only learn Present Tense in the first semester), to each person corresponds a different verbal form. But also here, there are models, rules, to make it easier to understand and to apply. And, actually, they understand these differences pretty fast, and already on their third week, are able to recognize the number and the gender, most of them.

Coming to a conclusion, I may only say that, for me, teaching my language in U.M. means, I need to consider the particularities from Malaysian students, using it to try to find a better way to teach them a different language, with a different structure, referring to another culture and way of life. I shall, everyday, improve my way of teaching, because I am getting to know them better and better, paying attention to the feed back I see (or not), the interest and the motivation they should show to me, in the classroom. If they are not motivated, my work will be $200 \%$ more difficult and with less results. So, I have to motivate them, in the beginning of each semester and each class (using everything I may correctly use for this purpose), and having them motivated, it will be possible for both of us, to work, to teach and to learn a new language (opening a door), having fun, by 
doing it. And this is the main reason why I like very much being here, and my students. Until now, already after 4 years, I should even say that I am impressed, each time more and more. When I compare my students in level 3 (1 semester corresponds to 1 level, around 56 hours) 2007, with my first level 3, 2 years ago, I notice they are much better now, even when I was already so proud, 2 years ago. I guess, being here also made it possible, for me, to become a better teacher, considering this kind of students, these conditions and, as a result, the students are better and better, already since level 1. It is a great feeling, to see and prove that! And, when they write small drama-scripts, in Portuguese, to perform at their oral exams, when they do it with all the motivation, creativity and material, in a way no teacher could possibly want them to do more, I realize that, maybe, I was able to do something good, here, because their results, are my own precious result.

\section{Referências Bibliográficas}

SIMÕES, Joao Gaspar (1991). Vida e Obra de Fernando Pessoa. Estudos Portugueses, Portugal, Publicações D. Quixote

CHARLIER, Francoise Dubois (1981). Bases de Análise Linguística. Lisboa: Ed. Almedina

CUNHA, Celso e CINTRA, Lindley (2001). Nova Gramática do

Português Contemporâneo. Rio de Janeiro: Editora Nova Fronteira.

CASIMIRO, Maria Cristiana A. P. C. (2007). Lendas e Outras Histórias de Timor. Fundação Mariana Seixas, Viseu, Portugal 


\section{AUTORA}

\section{Maria Cristiana Casimiro}

Professora de Português, Faculty of Languages and Linguistics, University of Malaya, Kuala Lumpur, Malaysia.

mcristianacasimiro@gmail.com

\section{Como citar este depoimento:}

CASIMIRO, Maria Cristiana. Teaching Portuguese as a foreign language, in University Malaya. Revista ACOALFAplp: Acolhendo a Alfabetização nos Países de Língua portuguesa, São Paulo, ano 2, n. 4, 2008. Disponível em: <http://www.mocambras.org $>$ e ou <http://www.acoalfaplp.org $>$. Publicado em: março 2008. 